Article

\title{
Specific Controlling Essential Oil Composition of Basil (Ocimum basilicum L.) Involving Low-Temperature, Low-Pressure Glow Plasma of Low Frequency
}

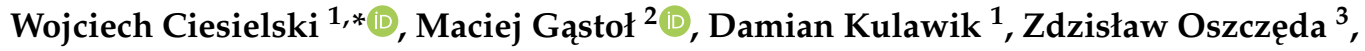 \\ Elżbieta Pisulewska ${ }^{4}$ and Piotr Tomasik ${ }^{3}$ \\ 1 Institute of Chemistry, Jan Długosz University, Armii Krajowej Ave. 13-15, 42201 Częstochowa, Poland; \\ d.kulawik@ujd.edu.pl \\ 2 Faculty of Biotechnology and Horticulture, University of Agriculture, 31-120 Krakow, Poland; \\ rogastol@cyfronet.pl \\ 3 Nantes Nanotechnological Systems, Dolnych Młynów Str. 24, 59700 Bolesławiec, Poland; \\ z.oszczeda@nantes.com (Z.O.); rrtomasi@cyf-kr.edu.pl (P.T.) \\ 4 Institute of Health and Economy, State Vocational College, 38400 Krosno, Poland; \\ elzbieta.pisulewska@gmail.com \\ * Correspondence: w.ciesielski@interia.pl
}

Received: 9 November 2020; Accepted: 25 November 2020; Published: 27 November 2020

\begin{abstract}
The effect of watering basil (Ocimum basilicum L.) with water treated with low-pressure, low-temperature glow plasma of low frequency (LPGP) on growth habits and plant metabolites was tested. Watering with the LPGP treated water was beneficial for sprouting basil seeds. Watering with non-treated water was advantageous solely for the number of leaves per plant and mass of one leaf. Watering with the LPGP treated water in contact with the air (LPGPA), nitrogen (LPGPN), carbon dioxide (LPGPC), and methane (LPGPM) increased the total yield of collected essential oil by $40 \%, 60 \%, 20 \%$, and 20\%, respectively. Watering with water treated under molecular oxygen (LPGPO) decreased that yield by $12.5 \%$. A diverse effect of particular kinds of the LPGP treated water upon the composition of isolated essential oil was also noted.
\end{abstract}

Keywords: aromas; fragrances; glow plasma; herbal medicine; spices

\section{Introduction}

Our recent paper [1] demonstrated how the functional properties of essential oil from lavender (Lavandula angustifolia, L) could be adjusted to its use as either a spice, fragrant for cosmetics, or in aroma therapy. It could be afforded by watering that plant with water treated with low-pressure, low-temperature glow plasma of low frequency (LPGP) [2,3]. Effects of watering depended on whether the treatment of water with LPGP was performed in contact with the air [4], nitrogen [5], carbon dioxide [6], molecular oxygen [7], or methane [8]

Thus, dihydrosabinene (thujone) dominated in essential oil from lavender watered with water treated under molecular oxygen (LPGPO). Essential oil collected from the plant watered with water threated under carbon dioxide (LPGPC) contained high level of pinenes. A high content of $\beta$-ocimene in essential oil from lavender watered with water treated in the air (LPGPA) made that oil a suitable as antifungal, antiviral, and anti-inflammatory product. For its high content of artemisole, essential oil from the plant watered with the water treated under molecular oxygen (LPGPO) could be recommended for curing various skin diseases. Whenever juniper aroma and the biological properties of herniarin 
used in dyspepsia and inadequate bile secretion were required, essential oil from lavender watered with water treated under nitrogen (LPGPN) could be recommended. Essential oil from lavender watered with water treated under methane (LPGPM) contained a high level of camphor and endo-borneol dup-1. Such results rationalize assumption that such kinds of LPGP treated water could be useful in controlled modifications of functional properties of other plants and their preparations.

In the present studies results of such approach to basil Ocimum basilicum L. is demonstrated. Plantations of that herb were watered with the water treated with LPGP in the air, under nitrogen, carbon dioxide, molecular oxygen, and methane. The effects of watering are given in terms of the quantitative characteristics of the basil crops and composition of the essential oils extracted from particular basil samples.

Basil, a herb, belongs to the Lamiaceae (mints) family. Although it originates from the region of central Africa to Southeast Asia [9], its plantations can be found worldwide. There are several species and cultivars of that plant which differ from one another with their specific tender, taste, flavour and aroma. Basil (Ocimum basilicum L.) belongs to the most common variety. It grows best outdoors as well as indoor including basements provided it is exposed to sun and fluorescent light, respectively. That herb is commonly used as a spice adding flavor and aroma [10-14] but these functional properties may depend on the breeding regime [10]. The plant and its essential oil contain $\beta$-carotene and a number of biologically active terpenes, aldehydes, alcohols, esters, phenols, ethers, and ketones as well as such bioelements as magnesium, iron, calcium, and zinc [15-20]. The most recent characteristics of basil and its essential oil were presented by Stanojevic et al. [21].

Biological functions of aqueous solutions of $O$. basilicum $\mathrm{L}$ are related to their hypoglycemic and hypolipidaemic activity [16]. The latter is based on the inhibition of the $\alpha$-glucosidase, which prevents the degradation of starch and sucrose, and consequently, control the absorption of level of blood sugar [22].

For its specific composition basil leaves and extracted essential oil are used for curing and inhibiting several diseases and health disorders [16,23]. The essential oil from basil showed antifungal and insect-repelling properties, [24] including potential toxicity to mosquitos [25]. In folk medicine, such as Ayurveda or traditional Chinese medicine, basil is thought to have therapeutic properties [26,27].

\section{Materials and Methods}

\subsection{Materials}

\subsubsection{Basil}

Seed material of basil 'Marian' was delivered by Enza Zaden Enterpraise (Enkhuizen, The Netherlands). As reported by the manufacturer, plants from those seeds provide dark green leaves of medium size and plants are resistant to diseases and tip burn and well tolerate low temperature and transport.

\subsubsection{Substrate}

Substrate was composed of medium size turf fraction Florabalt@Pot Medium-Coarse (Floragard, Oldenburg, Federal Republic of Germany). The medium of pH 5.6, contained $1.2 \mathrm{~g} / \mathrm{L}$ total salts including $210 \mathrm{mg} \mathrm{N} / \mathrm{L}, 120 \mathrm{mg} \mathrm{P}_{2} \mathrm{O}_{5} / \mathrm{L}, 260 \mathrm{mg} \mathrm{K} 2 \mathrm{O} / \mathrm{L}$. It was supplemented with multicomponent PG-Mix 18-10-20 fertilizer $\left(1.20 \mathrm{~kg} / \mathrm{m}^{3}\right.$ ) (Yara, Oslo, Norway)

\subsubsection{Water}

Tap water from Bolesławiec of total hardness $129 \mathrm{mg} / \mathrm{dm}^{3} \mathrm{CaCO}_{3}, \mathrm{pH} 7.1$, conductivity $334 \mu \mathrm{S} / \mathrm{cm}$, $\mathrm{Fe}<50 \mu \mathrm{g} / \mathrm{dm}^{3}, \mathrm{Mn}<5 \mu \mathrm{g} / \mathrm{dm}^{3}$ and $6.93 \mathrm{mg} / \mathrm{dm}^{3}$ dissolved oxygen was used as the standard. That water was LPGP treated for $30 \mathrm{~min}$ in contact with the air following to Białopiotrowicz et al. [4] 
providing LPGPA and, alternatively, treated for the same time with LGPG under nitrogen as described by Chwastowski et al. [5], providing LPGPN.

LPGPC, LPGPO and LPGPM were prepared following methods described by Chwastowski et al. [6-8]. LPGP of $38{ }^{\circ} \mathrm{C}$ was generated at $5 \times 10^{-3}$ mbar, $800 \mathrm{~V}, 50 \mathrm{~mA}$ and $10 \mathrm{KHz}$ frequency in a plasmothrone patented by Oszczęda et al. [2,3]. The produced water was stored at ambient temperature in $1 \mathrm{~L}$ closed teflon containers.

\subsubsection{Trays}

QP 15RW multiplates QP 15RW trays (Herkuplast Kubern GmbH, Ering/Inn, Federal Republic of Germany) were used. Each multiplate consisted of $3 \times 5$ trays. Each tray had $280 \mathrm{~cm}^{3}$ capacity. Further, $1 \mathrm{~m}^{2}$ of greenhouse hosted 880 plants.

\subsection{Methods}

\subsubsection{Basil plantation}

The monofactorial experiment was carried out from Feb 24th (sowing) till May 18th (harvesting) 2019 in a greenhouse at the University of Agriculture in Cracow. Temperature in the greenhouse was set for 22 and $18{ }^{\circ} \mathrm{C}$ during the day and night, respectively. The daytime took $16 \mathrm{~h}$ from dawn. The passing from the day into the night regime was controlled with computer. The automatic additional $16 \mathrm{~h}$ illumination with sodium lamps was used when natural light intensity decreased below $100 \mathrm{~W} / \mathrm{m}^{2}$. All plants were exposed to identical temperature, illumination, and humidity. The experiment involved three sets of trays with 24 pots each. Ten seeds of basil were sown into every pot. In one series of experiments 2 multiplates hosted 300 plants. In order to eliminate parietal effect 60 plants on the edge of trays were left apart and, therefore, only 240 plants were harvested. Since the experiments were run in triplicates maximum 720 plants were collected for a given series.

The watering was adjusted according to tensiometer readings (Irrometer model SR $150 \mathrm{~mm}$ ) when soil water tension was $<-40 \mathrm{kPa}$. The plants were watered by hand to avoid the accidental contact of water with leaves. Initially, plants consumed totally $3 \mathrm{~L}$ water, that is $1 \mathrm{~L}$ per each replication in the 5 day period until March 24th. In the subsequent 1-month period, the watering was intensified and the same amount of water was administered to the plants in 3-day periods. In the final period of breading plants were watered daily consuming the same amount of water. In such manner the watering consumed totally $40 \mathrm{~mL}$ each kind water daily. The experiment terminated on May 18th when the plants were collected and separated into leaves and stems. The plants were then dried at $105^{\circ} \mathrm{C}$ for 4 hours to determine dry mass of the crops.

\subsubsection{Preparation of Extracts}

Extracts were prepared on $30 \mathrm{~min}$. grounding of the plant material in a mortar $(20 \mathrm{~g})$ with $96 \%$ ethanol $\left(100 \mathrm{~cm}^{3}\right)$ added.

\subsubsection{Separation of Essential Oils}

Samples of the plant dried at $35^{\circ} \mathrm{C}$ to constant weight $(1 \mathrm{~g})$ were steam distilled in a Deryng apparatus with a closed water circulation. The collected oils were transferred to a closed vial and stored in dry ice until analyzed. Analysis was performed within three days.

\subsubsection{Gas Chromatographic Analyses}

Sample $(5 \mu \mathrm{L})$ was transferred to closed chromatographic viol and evaporated on a heating plate. Using gas-tight syringe gaseous sample $(10 \mu \mathrm{L})$ was analyzed using a Bruker 436-GC gas chromatograph coupled with Bruker SCION SQ (single quadruple, electron ionization) mass spectrometer (Durham, UK). The estimations were duplicated. 
The instrument was equipped with BR-5ms; $0.25 \mathrm{~nm} \times 30 \mathrm{~m}, \mathrm{df}=0.25 \mu \mathrm{m}$. The column operated at the following temperature programme: $50^{\circ} \mathrm{C}(2 \mathrm{~min})$ at the temperature rate increase $10^{\circ} \mathrm{C} / \mathrm{min}$ up to $170{ }^{\circ} \mathrm{C}(0 \mathrm{~min})$, then at $25^{\circ} \mathrm{C}$ to $280^{\circ} \mathrm{C}(5 \mathrm{~min})$.

Dispenser, transfer line, and the source temperature was 300,280 , and $200^{\circ} \mathrm{C}$, respectively. Sample separation was set for 1:20, helium was used as the carrier gas. The flow of the mobile phase was $1.0 \mathrm{~mL} / \mathrm{min}$, and ionization energy was $70 \mathrm{keV}$. Scanning was performed in the 50-500 m/z range.

Chromatographic signals were identified by comparison with mass spectra available in the NIST 11 library. The areas under particular chromatographic peaks were calculated using a computer programme installed in the chromatograph.

\subsection{Statistics}

The results were subjected to statistical interpretation, mean values and standard errors were calculated, and the significance of the variables was determined. Statistically significant differences between means $(p<0.05)$ were evaluated using one-way analysis of variance (ANOVA) with a post hoc multiply Duncan's range test [28]. Moreover, the Pearson product-moment correlation coefficients between analyzed variables were calculated. The significance level for correlation coefficient was $p=0.05$, and the number of pairs for the calculations was $N=216$. All statistical analyses were calculated using Statistica 13.3 software (Tibco Software Inc., Palo Alto, CA, USA).

\section{Results and Discussion}

The effect of watering depends, first of all, on the LPGP treated water macrostructure. On the treatment with LPGP that macrostructure was ruined forming smaller clusters. For that sake, water could more readily penetrate cell membranes. Simultaneously, declustreized water better solubilized several compounds. Thus, one could assume that water treated with LPGP could be better vector for dissolved components transporting them more efficiently to the flora and fauna cells.

The effect of the treatment of water with LPGP depended on the atmosphere in which the treatment was performed. Thus, solely LPGPA [4] and LPGPN [5] contained small structural units of aqueous clathrates. They hosted excited molecules of oxygen and nitrogen, respectively. Size of clathrates facilitated their permeation across cell membranes. LPGPA enriched interior of the cells in singlet molecular oxygen. Excited, singlet oxygen molecules liberated from their clathrates inside the cells released energy on returning to the normal triplet state. That energy could affect the course of cellular bioprocesses not necessarily resulting from the oxidation. LPGPN directed into the cells excited forms of molecular nitrogen.

All three LPGPC [6], LPGPO [7] and LPGPM [8] did not contain clathrates. Their macrostructures were stable to the extent dependent on proportion of involved hydrogen bonding configurations and the content of niches constituting these macrostructures. The macrostructure of LPGPM was relatively stable. It hosted methane molecules in its niches. In contrast to LPGPM, LPGPO carried in its niches molecular oxygen in the triplet state. The oxygen molecules participated in building the macrostructure. LPGPO clearly distinguished from the remaining kinds of water in its potential oxidative properties. LPGPC was built chiefly of surface tetrahedral and deformed tetrahedral structural units. The niches of its macrostructure incorporated O-free radicals of triplet carbon dioxide. Hence, one could anticipate different effects of those kinds of water upon the growth of O. basilicum L.

An insight into Table 1 provides an evidence that watering with LPGPA, LPGPN, LPGPC and LPGPO was beneficial for sprouting basil seeds. Solely LPGPM provided worse sprouting, although the effect was better than that noted for the plant watered with controlled non-treated water. The use of non-treated water was advantageous for the number of leaves per plant and mass of one leaf (Table 1). The benefit of watering with LPGP treated water was beneficial for the height of plants, total mass of crops, the total number of leaves, mass of stems, and total mass of foliage. 
Table 1. Quantitative characteristics of the basil crops ${ }^{\mathrm{a}}$.

\begin{tabular}{ccccccc}
\hline \multirow{2}{*}{ Estimation } & \multicolumn{7}{c}{ Plazmed Water } \\
\cline { 2 - 7 } & Non-Plazmed & LPGPA & LPGPN & LPGPC & LPGPM & LPGPO \\
\hline Number of plants & $3.04 \pm 0.15$ & $5.02 \pm 0.16$ & $4.79 \pm 0.33$ & $5.02 \pm 0.12$ & $4.96 \pm 0.13$ & $3.65 \pm 0.31$ \\
\hline Height of plants/pot $(\mathrm{cm})$ & $41.1 \pm 4.0$ & $56.4 \pm 2.1$ & $50.6 \pm 2.7$ & $57.6 \pm 1.7$ & $51.4 \pm 2.1$ & $44.6 \pm 2.1$ \\
\hline Total mass of plant $(\mathrm{g})$ & $11.52 \pm 0.51$ & $16.27 \pm 0.77$ & $15.14 \pm 0.55$ & $16.14 \pm 0.23$ & $16.11 \pm 0.35$ & $12.14 \pm 0.53$ \\
\hline Total number of leaves & $24.9 \pm 1.1$ & $33.2 \pm 1.2$ & $32.4 \pm 1.8$ & $33.4 \pm 1.4$ & $32.4 \pm 1.3$ & $27.3 \pm 1.1$ \\
\hline Number of leaves/plant & $8.39 \pm 0.23$ & $6.72 \pm 0.26$ & $7.14 \pm 0.34$ & $7.32 \pm 0.24$ & $6.95 \pm 0.24$ & $6.23 \pm 0.23$ \\
\hline Mass of stems (g) & $2.69 \pm 0.13$ & $5.29 \pm 0.19$ & $4.06 \pm 0.16$ & $4.26 \pm 0.21$ & $4.84 \pm 0.18$ & $4.78 \pm 0.13$ \\
\hline Total mass of foliage (g) & $8.33 \pm 0.39$ & $10.99 \pm 0.64$ & $11.08 \pm 0.48$ & $12.13 \pm 0.38$ & $11.98 \pm 0.23$ & $10.51 \pm 0.32$ \\
\hline Mass of one leaf (g) & $0.359 \pm 0.010$ & $0.337 \pm 0.019$ & $0.351 \pm 0.012$ & $0.337 \pm 0.018$ & $0.348 \pm 0.018$ & $0.334 \pm 0.017$ \\
\hline a Average number of plants collected from triplicated experiments involving $3 \times 24$ trays. Each tray contained \\
10 seeds. Presented data were recalculated for the number of plants in one tray.
\end{tabular}

The plants watered with the LPGP treated water were better shaped. The mass of the foliage was approximately $20 \%$ higher. Numbers of plants per one pot were about $20 \%$ higher. Similar effects of such watering were noted for the total mass of plants. The total number of leaves increased by approximately $40 \%$. Although LPGP treated water favored formation of the leaves, the latter were slightly smaller. Watering basil with LPGPA, LPGPM, and LPGPO increased the mass of stems by approximately $60-70 \%$. LPGPN and LPGPC provided hardly a $30-40 \%$ increase in the case of watering with LPGPN and LPGPC (Table 1).

Watering basil with LPGPA, LPGPN, LPGPC, and LPGPO considerably influenced the yield and composition of essential oils (Table 2). LPGPA, LPGPN, LPGPC, and LPGPM increased the total yield of collected essential oil by 40,60, 20 and 20\%, respectively, whereas LPGPO decreased that yield by $12.5 \%$.

Stanojevic et al. [21] recognized and characterized 65 components of essential oil from O. basilicum L. In this paper only components of $0.01 \%$ and higher yield were taken under consideration. Thus, essential oil extracted from the plants watered with control, non-treated water consisted of 33 characterized components (Table 2). Although watering those plants with LPGPA, LPGPN, LPGPC, and LPGPM increased the yield of collected oil its composition was impoverished in the number of components to $19,15,25$, and 25, respectively. Watering with LPGPO provided essential oil with 22 characterized components.

In the essential oil from basil watered with non-treated water dominated methyl eugenol (36.51\% of the total), linalool (14.25\%), eugenol (13.65\%), 1,8-cineole (7.15\%), and germacrene D (5.60\%).

Methyl eugenol, a phenolic compound, usually plays a role of attracting pollinator and a component of floral fragrance. It has some antifungal activity. It also repels many insects [29]. In 2018, Federal Drug Administration withdrawn authorization for the use of methyl eugenol as a synthetic flavoring substance in food. It was found that methyl eugenol induced cancer in laboratory animals [30]. From 2021 any product containing over $0.01 \%$ methyl eugenol has to be stated as per the CPL regulations [31]. LPGPA, LPGPN and LPGPC considerably increased the content of that compound in essential oil whereas LPGPO and, particularly, LPGPM decreased it.

Linalool, unsaturated alcohol, is widely used in perfumery and as insecticide [32], however, it can evoke some allergic responses [33]. It is considered as a potential drug for curingin some cancer diseases [34-36]. LPGPA, LPGPO, and LPGPM significantly increased the content of linalool in the essential oil but LPGPC and, particularly LPGPN, decreased it drastically.

Eugenol, a phenol, a typical fragrant compound which disposes also with antiseptic and anaesthetic properties. It is utilized, among others, in stomatology [37] and as an anticoagulant for blood cells [38]. LPGPA, LPGPN, and LPGPO decreased content of eugenol in essential oil whereas LPGPC considerably increased it. LPGPM had no effect upon the level of eugenol in that oil. 
Table 2. Composition of essential oil [ $\%$ of the total $=100 \%$ ] collected from basil watered with non-treated water, and water LPGP treated for 30 min either under air (LPGPA), nitrogen (LPGPN), carbon dioxide (LPGPC), molecular oxygen (LPGPO) and methane (LPGPM).

\begin{tabular}{|c|c|c|c|c|c|c|c|c|}
\hline $\begin{array}{c}\text { Peak Position } \\
\text { in } \\
\text { Chromatogram }\end{array}$ & $\begin{array}{l}\text { Retention } \\
\text { Time [min] }\end{array}$ & Component & $\begin{array}{l}\text { Non } \\
\text { Treated }\end{array}$ & LPGPA & LPGPN & LPGPC & LPGPO & LPGPM \\
\hline 1 & 7.08 & $\beta$-Thujone & 0.03 & - & 0.02 & 0.04 & 0.49 & 0.04 \\
\hline 2 & 7.27 & $\alpha$-Pinene & 0.11 & 0.03 & - & 0.03 & 0.16 & 0.09 \\
\hline 3 & 7.68 & Camphene & 0.04 & - & 0.01 & 0.03 & 0.02 & - \\
\hline 5 & 8.22 & Sabinene & 0.51 & 0.27 & 0.28 & 0.14 & 8.25 & 2.68 \\
\hline 9 & 8.60 & $\beta$-Pinene & 2.31 & 2.44 & 0.21 & 0.48 & 2.09 & 1.92 \\
\hline 10 & 8.79 & $\alpha$-Caryphyllene & - & - & 0.03 & 1.28 & - & - \\
\hline 15 & 9.37 & p-Cymene & - & - & - & 0.97 & - & - \\
\hline 16 & 9.51 & o-Cymene & 0.17 & 0.14 & 2.55 & 2.31 & 0.05 & 0.06 \\
\hline 17 & 9.63 & D-Limonene & 2.82 & 2.23 & 0.06 & 0.10 & 1.60 & 3.84 \\
\hline 19 & 9.71 & Eucalyptol & 2.36 & - & - & - & 3.68 & 4.52 \\
\hline 27 & 11.40 & Linalool & 14.25 & 18.54 & 1.85 & 8.15 & 19.16 & 18.42 \\
\hline 29 & 11.98 & Fenchone & 0.14 & - & - & 0.25 & - & - \\
\hline 32 & 12.50 & $\alpha$-Bulnesene & 0.14 & - & - & - & 0.04 & 0.04 \\
\hline 35 & 12.89 & Fenchyl acetate & 0.38 & 0.33 & - & - & 0.24 & - \\
\hline 39 & 13.19 & $\beta$-Cubebene & - & - & 0.05 & 0.06 & - & - \\
\hline 47 & 13.84 & Isocaryophyllene & 0.29 & - & - & - & - & 0.12 \\
\hline 54 & 14.91 & 4-Carvomenthol & - & - & - & 0.65 & - & - \\
\hline 62 & 15.81 & Carveol & 0.18 & - & - & - & 0.68 & - \\
\hline 63 & 15.82 & Lavandulol acetate & - & - & - & 1.48 & - & 1.25 \\
\hline 64 & 15.92 & Bornyl acetate & 0.05 & - & - & - & 0.06 & 0.05 \\
\hline 73 & 17.45 & Eugenol & 13.65 & 8.56 & 9.41 & 16.84 & 6.51 & 13.69 \\
\hline 75 & 17.62 & Methyl eugenol & 36.51 & 40.58 & 58.62 & 41.85 & 35.41 & 23.77 \\
\hline 77 & 17.96 & Geranyl acetate & 0.23 & 0.06 & - & - & 0.17 & 0.16 \\
\hline 78 & 18.02 & $\beta$-Elemene & 0.34 & - & - & 3.25 & 2.19 & - \\
\hline 79 & 18.03 & Copaene & 0.35 & - & - & 1.25 & - & 0.95 \\
\hline 80 & 18.79 & $\alpha$-Bergamotene & 0.95 & 3.24 & - & 4.27 & - & 1.68 \\
\hline 82 & 18.97 & Caryophyllene & 1.25 & 0.54 & - & 0.82 & 1.30 & 1.30 \\
\hline 85 & 19.06 & $\beta$-Eudesmol & 1.52 & - & - & - & - & - \\
\hline 87 & 19.59 & Geranyl propionate & 0.57 & 2.38 & - & - & 3.28 & 4.62 \\
\hline 90 & 20.02 & $\alpha$-Farnesene & 2.36 & 1.89 & 5.23 & - & 1.20 & 0.18 \\
\hline 92 & 20.16 & $\gamma$-Cadinene & 1.28 & 5.28 & - & 2.56 & - & 3.99 \\
\hline 93 & 20.20 & $\sigma$-Cadinene & 0.30 & - & - & - & - & - \\
\hline 94 & 20.74 & 1,8-Cineole & 7.15 & 3.41 & 8.14 & 4.28 & 0.25 & 6.58 \\
\hline 95 & 20.80 & Germacrene D & 5.60 & 1.57 & 0.02 & 0.02 & - & 0.06 \\
\hline 96 & 21.03 & 1,10-di-epi-Cubenol & 0.25 & 0.03 & - & - & - & - \\
\hline 97 & 21.18 & 1-epi-Cubenol & 0.15 & - & - & 0.62 & 0.38 & 0.45 \\
\hline 98 & 21.21 & $\tau$-Cadinol & 0.24 & - & - & - & - & - \\
\hline 99 & 21.68 & Estragole & 3.52 & 8.48 & 4.52 & 8.27 & 12.79 & 9.54 \\
\hline \multicolumn{3}{|c|}{ Total number of components } & 33 & 19 & 15 & 25 & 22 & 25 \\
\hline \multicolumn{3}{|c|}{ Yield of essential oil (mL/100 g dry mass) ${ }^{a}$} & 0.5 & 0.7 & 0.8 & 0.6 & 0.4 & 0.6 \\
\hline
\end{tabular}

${ }^{a}$ In every case accuracy of the estimation was \pm 0.02 . The dash in particular position denotes an absence of given compound in the corresponding essential oil.

The terpene 1,8-Cineole (eucalyptol) is used as an insecticide and insect repellent [39,40] and insect pheromone [41,42]. In higher-than-normal doses, eucalyptol is hazardous via either ingestion, skin contact or inhalation. It is classified as a reproductive toxin for females and a suspected reproductive toxin for males [43]. Anti-inflammatory properties of eucalyptol are also reported [44]. 
LPGPN increased the eucalyptol content in the essential oil, whereas the remaining types of treated water, particularly LPGPO, decreased it.

Germacrene D, a sesquiterpene, has antimicrobial and insecticidal properties [45]. It constituted $5.6 \%$ of the essential oil from basil watered with non-treated water. The watering with all LPGP treated kinds of water significantly reduced its level.

Watering basil with LPGPO enriched content of sabinene in the essential oil from $0.51 \%$ to $8.25 \%$. It could be beneficial for the bactericidal properties of that monoterpene. Sabinene exhibits also anti-fungal activity against pathogenic fungi [46]. LPGPM elevated the sabinene content to $2.68 \%$ and the other kinds of LPGP treated water had no effect on it.

It is worth to mention that LGPGN increased by over twice the content of $\alpha$-farmesene. In essential oil from basil watered with non-treated water, the content of $\alpha$-farmesene reached hardly $2.36 \%$. That terpene acts as alarm pheromone in termites [47] and food attractant for codling moth, the apple tree pest [48].

Essential oil from basil watered with non-treated water contained $3.52 \%$ estragole. LPGPN increased the content of that compound to $4.52 \%$ but LPGPC, LPGPA, LPGPM and LGPGO rose that content to $8.27 \%, 8.48 \%, 9.54 \%$, and $12.79 \%$, respectively. These results were alarming because, as indicated by the European Union Committee on Herbal Medicinal Products [49,50], estragole is carcinogenic and genotoxic.

Insights shown in Table 2 revealed that the application of particular kinds of LPGP treated water also influenced the content of components residing in essential oils in below $5 \%$ concentration. For instance, every kind of LPGP treated water completely eliminated $\tau$-cadinol, $\beta$-eudesmol and $\alpha$-cadinene. On the other hand, in essential oils isolated from basil watered with LPGP treated water, some components absent in original oil could be found. They were $\alpha$-capryllene, p-cymene, $\beta$-cubebene, 4-carvomenthol and lavandulol acetate.

An explanation of the mechanisms of biosynthesis of particular components of the essential oil would require separate studies. However, one may speculate in advance on the role of particular kinds of the LPGP-treated water applied in the biosynthesis of components of essential oil.

The terpenes formed initially are subjected to further enzymatic modifications, including various modes of oxidation, reduction, isomerization and conjugation. These reactions produce several terpenoids found in that plant. The enzymes responsible for relevant transformations are not restricted to terpenoid biosynthesis. A specific hydroxylation catalyzed by the cytochrome $\mathrm{P}_{450}$-dependent oxigenases can also be taken into account [51].

The presence of molecular oxygen in LPGPO can rationalize the elevated level of sabinene whose biosynthesis takes place mainly in the plastids. The biosynthesis of sesquiterpenes $\alpha$-caryphyllene and germacrene $\mathrm{D}$ is restricted to the cytosol [52]. The inhibition of the $\alpha$-caryophyllene and germacrene biosynthesis, and at the same time stimulation of biosynthesis of sabinene, can be rationalized involving the oxidative potential of LPGPO in plastid where the compound is formed involving monoterepene synthases [1]. On the other hand, the biosynthesis of sesquiterpenes is restricted to the cytosol. There are different mechanisms of the synthetases regulation which could be responsible for observed differences [53]. Several transformations of terpenoids (either hydroxylation or epoxidations) involved insertion of the oxygen atoms into their skeletons. They were provided by cytochrome P-450 mixed-function oxidase, e.g., oxidation of acyclic monoterpene alcohols [54] and glucosylation of diterpene alcohols by glucotransferases [55]. Supposedly, the cytochrome P450 enzymes involved in the terpenoid secondary metabolism in plants are substrate specific [56,57]. The striking difference of biosynthesis level of germacrene and $\beta$-elemene on watering basil with LPGPO can result from the stereo-specificity of appropriate hydroxylases. There is a strong similarity in three-dimensional structure of germacrene and $\beta$-elemene. 


\section{Conclusions}

Watering basil with water treated with properly adjusted low-pressure, low-temperature glow plasma of low frequency provides a manipulation with the yield of herb crops and their functional properties. Generally, watering with water treated with glow plasma increased number of plants, height of plants, total mass of plants, total number of leaves, total mass of foliage. These parameters depended on the kind of plazmed water. Solely mass of one leave and number of leaves per plant were slightly higher in plants watered with non-treated water.

Application of particular kinds of water treated with low-temperature, low-pressure glow plasma of low frequency influenced the content of components and yield of the essential oils. Essential oil from the plant watered with non-treated water was the richest in the number of components. At the same time, watering with water treated with glow plasma under nitrogen provided the highest yield of the oil, but the poorest in terms of the number of components.

Author Contributions: W.C. run determination of separation of essential oils, D.K. gas chromatographic analyses, M.G. run basil cultivation, E.P. run basil cultivation, Z.O. equipped a research team in nanowater, P.T. invented the project, coordinated study and designed the text of this report. All authors jointly participated in interpretation of all data and in writing report. All authors have read and agreed to the published version of the manuscript.

Funding: This research did not receive any specific grant from funding agencies in the public, commercial, or not-for-profit sectors.

Conflicts of Interest: No conflict of interest is known to the authors.

\section{References}

1. Ciesielska, K.; Ciesielski, W.; Girek, T.; Kołoczek, H.; Oszczęda, Z.; Tomasik, P. Reaction of Lavandula angustifolia Mill. to water treated with low-temperature, low-pressure glow plasma of low frequency. Water 2020. accepted. [CrossRef]

2. Oszczęda, Z.; Elkin, I.; Stręk, W. Equipment for Treatment of Water with Plasma. Polish Patent PL 216025 B1, 28 February 2014.

3. Reszke, E.; Yelkin, I.; Oszczęda, Z. Plasming Lamp with Power Supply. Polish Patent PL 227530 B1, 26 October 2017.

4. Białopiotrowicz, T.; Ciesielski, W.; Domański, J.; Doskocz, M.; Fiedorowicz, M.; Grąż, K.; Khachatryan, K.; Kołoczek, H.; Kozak, A.; Oszczęda, Z.; et al. Structure and physicochemical properties of water treated with low-temperature low- frequency plasma. Curr. Phys. Chem. 2016, 6, 312-320. [CrossRef]

5. Chwastowski, J.; Ciesielska, K.; Ciesielski, W.; Khachatryan, K.; Koloczek, H.; Kulawik, D.; Oszczęda, Z.; Tomasik, P.; Witczak, M. Structure and Physicochemical Properties of Water Treated under Nitrogen with Low-Temperature Glow Plasma. Water 2020, 12, 1314. [CrossRef]

6. Ciesielska, A.; Ciesielski, W.; Khachatryan, K.; Koloczek, H.; Kulawik, D.; Oszczeda, Z.; Soroka, J.A.; Tomasik, P. Structure and Physicochemical Properties of Water Treated under Carbon Dioxide with Low-Temperature Low-Pressure Glow Plasma of Low Frequency. Water 2020, 12, 1920. [CrossRef]

7. Chwastowski, J.; Ciesielski, W.; Khachatryan, K.; Kulawik, D.; Kulawik, D.; Oszczęda, Z.; Soroka, J.A.; Tomasik, P.; Witczak, M. Water of Increased Content of Molecular Oxygen. Water 2020, 12, 2488. [CrossRef]

8. Ciesielska, A.; Ciesielski, W.; Khachatryan, K.; Koloczek, H.; Kulawik, D.; Oszczeda, Z.; Soroka, J.A.; Tomasik, P. Structure and Physicochemical Properties of Water Treated under Methane with Low-Temperature Glow Plasma of Low Frequency. Water 2020, 12, 1638. [CrossRef]

9. Simon, J.E. Basil; Center for New Crops \& Plant Products, Department of Horticulture, Purdue University: West Lafayette, IN, USA, 1995.

10. Sajjadi, S.E. Analysis of the essential oils of two cultivated basil (Ocimum basilicum L.) from Iran. DARU J. Pharm. Sci. 2006, 14, 128-130.

11. Telci, I.; Bayram, E.; Yılmaz, G.; Avc1, B. Variability in essential oil composition of Turkish basils (Ocimum basilicum L.). Biochem. Syst. Ecol. 2006, 34, 489-497. [CrossRef]

12. Nowak, J. Basil Rośliny Ozdobne; Instytut Sadownictwa w Skierniewicach: Skierniewice, Poland, $2014 ;$ p. 5. (In Polish) 
13. Andrzejewska, J.; Pisulewska, E. Breeding of Herbal Plants; Editorial Board of the Technical and Life Science University: Bydgoszcz, Poland, 2019. (In Polish)

14. Carroll, A.; De Persiis Vona, E.; De Persiis Vona, G. The Dictionary of Foods: A Passionate A-to-Z Guide to the Earth's Healthy Offerings with More than 140 Delicious Nutrient Recipes; Da Capo Press: Boston, MA, USA, 2020; ISBN 978-1-56924-395-4.

15. Grayer, R.J.; Kite, G.C.; Goldstone, E.J.; Bryan, S.E.; Paton, A.; Putievsky, E. Intraspecific taxonomy and essential oil chemotypes in Sweet basil, Ocinum basilicum. Phytochemistry 1996, 43, 1033-1039. [CrossRef]

16. Volpato, G.T.; Damasceno, D.C.; Calderon, I.M.P.; Rudge, M.V.C. Review of Brazilian plants with proven hypoglycemic effect in the control of diabetes mellitus. Rev. Bras. Plant. Med. 2002, 4, 35-45.

17. Jayasinghe, C.; Gotoh, N.; Aoki, A.T.; Wada, S. Phenolics Composition and Antioxidant Activity of Sweet Basil (Ocimum basilicum L.). J. Agric. Food Chem. 2003, 51, 4442-4449. [CrossRef] [PubMed]

18. Burt, S. Essential oils: Their antibacterial properties and potential applications in foods-A review. Int. J. Food Microbiol. 2004, 94, 223-253. [CrossRef] [PubMed]

19. Lee, S.J.; Umano, K.; Shibamoto, T.; Lee, K.G. Identification of volatile components in basil (Ocimum basilicum L.) and thyme leaves (Thymus vulgaris L.) and their antioxidant properties. Food Chem. 2005, 91, 131-137. [CrossRef]

20. Jelacic, S.; Beatovic, D.; Prodanović, S.; Tasic, S.; Moravcevic, D.; Vujosevic, A.; Vuckovic, S. Chemical composition of the essential oil of basil (Ocimum basilicum L. Lamiaceae). Chem. Ind. 2011, 65, 465-471. [CrossRef]

21. Stanojevic, L.P.; Marjanovic-Balaban, Z.R.; Kalaba, V.D.; Stanojevic, J.S.; Cvetkovic, D.J.; Cakic, M.D. Chemical composition, antioxidant and antimicrobial activity of basil (Ocinum basilicum L.) essential oil. TEOP 2017, 20, 1537-1569.

22. Wongsa, P.; Chaiwarit, J.; Zamaludien, A. In vitro screening of phenolic compounds, potential inhibition against $\alpha$-amylase and $\alpha$-glucosidase of culinary herbs in Thailand. Food Chem. 2012, 131,964-971. [CrossRef]

23. Gupta, S.K.; Prakash, J.; Srivastava, S. Validation of traditional claim of Tulsi Ocimum sanctum Linn. as a medicinal plant. Indian J. Exp. Biol. 2002, 40, 765-773.

24. Dube, S.; Upadhhyay, P.D.; Tripath, S.C. Antifungal, physicochemical, and insect- repelling activity of the essential oil of Ocimum basilicum. Can. J. Botany 1989, 67, 2085-2087. [CrossRef]

25. Maurya, P.; Sharma, P.; Mohan, L.; Batabyal, L.; Srivastava, C. Evaluation of the toxicity of different phytoextracts of Ocimum basilicum against Anopheles stephensi and Culex quinquefasciatus. J. Asia-Pac. Èntomol. 2009, 12, 113-115. [CrossRef]

26. Grayer, R.J. Basil. The genus Ocimum. Phytochemistry 2001, 58, 533. [CrossRef]

27. Lupton, D.; Khan, M.M.; Al-Yahai, R.A.; Hanif, M.A. Basil (in) Leafy Medicinal Herbs, Chemistry, Technology and Uses; Chapter 3; Ambrose, D.C.P., Manickavasagan, A., Naik, R., Eds.; CABI: Boston, MA, USA, 2016; ISBN 9781780645599.

28. Duncan, D.B. Multiple Range and Multiple F Tests. Biometrics 1955, 11, 1-42. [CrossRef]

29. Nishida, R.; Tan, K.H. Methyl eugenol: Its occurrence, distribution and role in nature, especially in relation to insect behaviour and pollination. J. Insect Sci. 2012, 12, 1-60.

30. Federal Register, Regulations: Synthetic Flavouring Agents and Adjuvants. 2018. Available online: https://www.govinfo.gov/app/details/FR-2018-10-09/2018-21807 (accessed on 9 October 2020).

31. European Community. Regulation No. 1272/2008. Available online: https://eur-lex.europa.eu/legal-content/ EN/TXT/?uri=CELEX\%3A32008R1272 (accessed on 5 September 2020).

32. Govindarajan, M.; Sivakumar, R.; Rajeswary, M.; Yogalakshmi, K. Chemical composition and larvicidal activity of essential oil from Ocimum basilicum (L.) against Culex tritaeniorhynchus, Aedes albopictus and Anopheles subpictus (Diptera: Culicidae). Exp. Parasitol. 2013, 134, 7-11. [CrossRef] [PubMed]

33. Ung, C.Y.; White, J.M.L.; White, I.; Banerjee, P.; McFadden, J.P. Patch testing with the European baseline series fragrance markers: A 2016 update. Br. J. Dermatol. 2018, 178, 776-780. [CrossRef]

34. Gu, Y.; Ting, Z.; Qiu, X.; Zhang, X.; Gan, X.; Fang, Y.; Xu, X.; Xu, R. Linalool preferentially induces robust apoptosis of a variety of leukemia cells via upregulating p53 and cyclin-dependent kinase inhibitors. Toxicology 2010, 268, 19-24. [CrossRef]

35. Chang, M.-Y.; Shieh, D.-E.; Chen, C.-C.; Yeh, C.-S.; Dong, H.-P. Linalool Induces Cell Cycle Arrest and Apoptosis in Leukemia Cells and Cervical Cancer Cells through CDKIs. Int. J. Mol. Sci. 2015, 16, 28169-28179. [CrossRef] [PubMed] 
36. Iwasaki, K.; Zheng, Y.-W.; Murata, S.; Ito, H.; Nakayama, K.; Kurokawa, T.; Sano, N.; Nowatari, T.; Villareal, M.O.; Nagano, Y.N.; et al. Anticancer effect of linalool via cancer-specific hydroxyl radical generation in human colon cancer. World J. Gastroenterol. 2016, 22, 9765. [CrossRef] [PubMed]

37. Nikonorow, M.; Urbanek-Karłowska, B. Food Toxicology; PZWl: Warsaw, Poland, 1987. (In Polish)

38. Tognolini, M.; Barocelli, E.; Ballabeni, V.; Bruni, R.; Bianchi, A.; Chiavarini, M.; Impicciatore, M. Comparative screening of plant essential oils: Phenylpropanoid moiety as basic core for antiplatelet activity. Life Sci. 2006, 78, 1419-1432. [CrossRef] [PubMed]

39. Klocke, J.A.; Darlington, M.V.; Balandrin, M.F. 1,8-Cineole (Eucalyptol), a mosquito feeding and ovipositional repellent from volatile oil of Hemizonia fitchii (Asteraceae). J. Chem. Ecol. 1987, 13, 2131-2141. [CrossRef]

40. Sfara, V.; Zerba, E.N.; Alzogaray, R.A. Fumigant insecticidal activity and repellent effect of five essential oils and seven monoterpenes on first-instar nymphs of Rhodnius prolixus. J. Med Èntomol. 2009, 46, 511-515. [CrossRef]

41. Schiestl, F.P.; Roubik, D.W. Odor compound detection in male euglossine bees. J. Chem. Ecol. 2003, 29, $253-257$. [CrossRef]

42. Schemske, U.W.; Lande, R. Fragrance collection and territorial display by male orchid bees. Anim. Behav. 1984, 32, 935-937. [CrossRef]

43. Material Safety Data Sheet-Cineole. ScienceLab, 2012. Available online: https://web.archive.org/web/ 20120829230700/http://www.sciencelab.com/msds.php?msdsId=9924005 (accessed on 9 July 2020).

44. Caceres, A.I.; Liu, B.; Jabba, S.V.; Achanta, S.; Morris, J.B.; Jordt, S.-E. Transient Receptor Potential Cation Channel Subfamily M Member 8 channels mediate the anti-inflammatory effects of eucalyptol. Br. J. Pharmacol. 2017, 174, 867-879. [CrossRef]

45. Ali, P.; Chen, Y.-F.; Sargsyan, E. Bioactive Molecules of Herbal Extracts with Anti-Infective and Wound Healing Properties. In Microbiology for Surgical Infections; Academic Press: Cambridge, MA, USA, 2014; pp. 205-220.

46. Arunkumar, R.; Nair, S.A.; Rameshkumar, K.B.; Subramoniam, A. The essential oil constituents of Zornia diphylla (L.) Pers, and anti-inflammatory and antimicrobial activities of the oil. Rec. Nat. Prod. 2014, 8, 385-393.

47. Šobotník, J.; Hanus, R.; Kalinová, B.; Piskorski, R.; Cvačka, J.; Bourguignon, T.; Roisin, Y. (E,E)- $\alpha$-farnesene, an alarm pheromone of the termite Prorhinotermes canalifrons. J. Chem. Ecol. 2008, 34, 478-486. [CrossRef]

48. Hern, A.; Dorn, S. Sexual dimorphism in the olfactory orientation of adult Cydia pomonella in response to alpha-farnesene. Èntomol. Exp. Appl. 1999, 92, 63-72. [CrossRef]

49. Committee on Herbal Medicinal Products. Final Public Statement on the Use of Herbal Medicinal Products Containing Estragole, EMEA/HMPC/137212/2005. Available online: http://www.ema.europa.eu/docs/en_GB/ document_library/Scientific_guideline/2010/04/WC500089960.pdf (accessed on 19 September 2020).

50. SCF/CS/FLAV/FLAVOUR/6. Opinion of the Scientific Committee on Food on Estragole (1-Allyl-4-methoxybenzene); Scientific Committee on Food: Brussels, Belgium, 26 September 2001. Available online: https://web.archive.org/web/20070302102822/http://ec.europa.eu/food/fs/sc/scf/out104_en. pdf (accessed on 19 September 2020).

51. Hallahan, D.L.; West, J.M.; Smiley, D.W.M.; Picket, J.A. Nepetalactol oxireductase in trichomes of the catmint Nepeta racemosa. Phytochemistry 1998, 48, 421-427. [CrossRef]

52. Gleizes, M.; Pauly, G.; Carde, J.-P.; Marpeau, A.; Bernard-Dagan, C. Monoterpene hydrocarbon biosynthesis by isolated leucoplasts of Citrofortunella mitis. Planta 1983, 159, 373-381. [CrossRef]

53. Back, K.; Chappeli, J. Cloning and bacterial expression of a sesquiterpene cyclases from Hyoscyamus muticus and its molecular comparision to related terpene cyclases. J. Biol. Chem. 1995, 270, 7375-7381. [CrossRef]

54. Keller, Y.; Bouvier, F.; Dharlingue, A.; Camara, B. Metabolic compartmentation of plastid prenyllipid biosynthesis: Evidence for the involment of a multifuctional geranylgeranyl reductase. Eur. J. Biochem. 1998, 251, 413-417. [CrossRef]

55. Shibata, H.; Sawa, Y.; Oka, T.; Sonoke, S.; Kim, K.K. Steviol and steviol-Glycoside: Glucotransferase activities in Stevia rebaudiana Bertoni-Purification and partial characterization. Arch. Biochem. Biophys. 1995, 321, 390-396. [CrossRef] [PubMed]

56. West, C.A. Biosynthesis of Diterpenes. In Biosynthesis of Isoprenoid Compounds; Porter, J.W., Spurgeon, S.L., Eds.; John Wiley and Sons: New York, NY, USA, 1981; pp. 376-411. 
57. Mihaliak, C.A.; Karp, F.; Croteau, R. Cytochrome P450 Terpene Hydroxylases. In Enzymes of Secondary Metabolism; Lea, P.J., Ed.; Academic Press: London, UK, 1993; pp. 261-279.

Publisher's Note: MDPI stays neutral with regard to jurisdictional claims in published maps and institutional affiliations.

(C) 2020 by the authors. Licensee MDPI, Basel, Switzerland. This article is an open access article distributed under the terms and conditions of the Creative Commons Attribution (CC BY) license (http://creativecommons.org/licenses/by/4.0/). 